\title{
Pengaruh Laju Pengadukan Terhadap Stabilitas Digester Anaerobik Satu Tahap pada Pembentukan Biogas dari Limbah Cair Pabrik Kelapa Sawit Menggunakan Lab Scale Reaktor Batch
}

\author{
Effect of Mixing Rate to Stability of One-Stage Anaerobic Digester on Biogas Production \\ From Palm Oil Mill Effluent Using a Lab Scale Batch Reactor
}

\author{
Irvan*, Bambang Trisakti, Nawalul Azka \\ Departemen Teknik Kimia, Fakultas Teknik, Universitas Sumatera Utara, Jalan Almamater Kampus USU, \\ Medan, 20155, Indonesia \\ *Email: irvan@usu.ac.id
}

\begin{abstract}
Abstrak
Pencampuran berfungsi untuk meningkatkan efisiensi interaksi antara mikroba aktif dan bahan organik selama proses digestasi anaerobik. Tujuan penelitian ini adalah studi pengaruh laju pengadukan terhadap stabilitas digester anaerobik satu tahap dalam produksi biogas yang ditinjau dari $\mathrm{pH}$ dan alkalinitas. Pembuatan biogas dari limbah cair pabrik kelapa sawit dilakukan pada reaktor batch 6000 $\mathrm{ml}$ pada variasikan laju pengadukan $100 \mathrm{rpm}, 150 \mathrm{rpm}, 200 \mathrm{rpm}, 250 \mathrm{rpm}$ dan $300 \mathrm{rpm}$. Reaktor dioperasikan dengan kondisi campuran dijaga pada $\mathrm{pH} 7 \pm 0,2$ dan suhu operasi $55^{\circ} \mathrm{C}$. Pada campuran ditambahkan $\mathrm{NaHCO}_{3}$ untuk mengontrol dan menjaga $\mathrm{pH}$ campuran. Analisis $\mathrm{pH}$ dan alkalinitas dilakukan setiap hari untuk melihat stabilitas reaktor. Hasil terbaik diperoleh pada laju pengadukan 200 rpm dengan $\mathrm{pH}$ yang dihasilkan stabil selama proses yaitu 7. Profil alkalinitas yang dihasilkan pada setiap laju pengadukan relatif stabil dengan rentang alkalinitas yaitu $3500-4500 \mathrm{mg} / \mathrm{L}$. Laju pengadukan terbaik yaitu $200 \mathrm{rpm}$ dengan nilai $\mathrm{pH}$ dan alkalinitas stabil dan produksi biogas tertinggi yaitu sebesar $457 \mathrm{ml} / \mathrm{hari}$.
\end{abstract}

Kata kunci: biogas, digestasi anaerobik, laju pengadukan, limbah cair kelapa sawit

\begin{abstract}
Mixing is essential to increase the efficiency of interactions between active microbes and organic matter during the anaerobic digestion process. The purpose of this research is to study the effect of mixing rate on the stability of one stage anaerobic digesters in biogas production in terms of $\mathrm{pH}$ and alkalinity. The production of biogas from palm oil mill effluent was carried out in a $6000 \mathrm{ml}$ batch reactor at varying mixing rates: $100 \mathrm{rpm}, 150 \mathrm{rpm}, 200 \mathrm{rpm}, 250 \mathrm{rpm}$, and $300 \mathrm{rpm}$. The reactor is operated with a mixture condition maintained at a pH of $7 \pm 0.2$ and an operating temperature of $55^{\circ} \mathrm{C}$. $\mathrm{NaHCO}_{3}$ is added to the mixture to control and maintain the $\mathrm{pH}$ of the mixture. Analysis of $\mathrm{pH}$ and alkalinity is carried out every day to see the reactor stability. The best results were obtained at a mixing rate of $200 \mathrm{rpm}$ with the $\mathrm{pH}$ produced stable during the process is 7 . The alkalinity profile produced at each mixing rate was relatively stable with an alkalinity range is $3500-4500 \mathrm{mg} / \mathrm{L}$. The best mixing rate is $200 \mathrm{rpm}$ with a stable $\mathrm{pH}$ and alkalinity and the highest biogas production is $457 \mathrm{ml} / \mathrm{day}$.
\end{abstract}

Keywords: anaerobic digestion, biogas, mixing rate, palm oil mill effluent

\section{Pendahuluan}

Minyak kelapa sawit merupakan salah satu komoditas utama di Indonesia dan dalam beberapa tahun terakhir telah meningkat penggunaannya seperti pada industri makanan, biofuel, dan kosmetik. Penggunaan minyak kelapa sawit di pabrik untuk memasok permintaannya menghasilkan residu yang sangat berpolusi yang disebut dengan Limbah Cair Kelapa Sawit (LCPKS) [1], sehingga harus diolah terlebih dahulu karena dapat mencemari lingkungan. Salah satu pengolahan LCPKS yaitu dengan memanfaatkan LCPKS menjadi biogas dengan metode Anaerobic Digestion (AD).

Energi terbarukan biogas yang berasal dari LCPKS ini dapat membantu mengurangi penggunaan bahan bakar fosil konvensional dan pada saat yang sama biogas dari LCPKS berkontribusi untuk menjaga lingkungan. Selain itu, pengolahan LCPKS dengan metode anaerob juga menghasilkan air dan pupuk organik [2], yang dapat digunakan untuk pertanian.

Jumlah biogas yang dihasilkan oleh proses AD bergantung pada beberapa parameter seperti suhu, $\mathrm{pH}$, $\mathrm{TS}$, rasio $\mathrm{C} / \mathrm{N}, \mathrm{COD}$, pengadukan, dan reaktor set up 
[3]. Pencampuran atau agitasi berfungsi untuk memberikan interaksi yang efisien antara mikroba aktif dan bahan organik, mencegah pengendapan bahan, mencapai homogenitas bahan, dan menghindari pengembangan gradien suhu dalam sistem AD [4]. Tujuan penelitian ini adalah studi pengaruh laju pengadukan terhadap stabilitas digester anaerobik satu tahap dalam produksi biogas yang ditinjau dari $\mathrm{pH}$ dan $\mathrm{M}$-Alkalinity.

\section{Teori}

Anaerobic digestion (AD) adalah salah satu metode pengolahan limbah cair yang mengandung konsentrasi karbon organik tinggi seperti LCPKS. Metode ini memiliki keunggulan yaitu hemat biaya, ramah lingkungan, mengurangi jumlah lumpur dan mampu menghasilkan listrik dari metana [5].

Proses mikrobiologis pada AD yaitu hidrolisis, asidogenesis, asetogenesis, dan metanogenesis. Proses-proses ini mengubah konstituen POME yang mengandung karbohidrat, asam lemak, dan protein menjadi biogas [1]. Biogas yang dihasilkan terdiri dari $65 \% \mathrm{CH}_{4}, 35 \% \mathrm{CO}_{2}$, dan sejumlah kecil hidrogen sulfida $\left(\mathrm{H}_{2} \mathrm{~S}\right)$, yang merupakan produk akhir $\mathrm{AD}$. Metana yang dihasilkan berpotensi menggantikan bahan bakar fosil sebagai sumber energi [6].

Jumlah biogas yang dihasilkan oleh proses AD bergantung pada beberapa parameter seperti suhu, $\mathrm{pH}$, $\mathrm{TS}$, rasio $\mathrm{C} / \mathrm{N}, \mathrm{COD}$, pengadukan, dan reaktor set up [3]. Pengadukan pada sistem batch berfungsi untuk meningkatkan homogenisasi campuran substrat (LCPKS) dan mikroorganisme [7]. Pengadukan juga dilakukan untuk mencegah terjadinya benda mengambang di permukaan cair dan untuk mendapatkan suhu yang seragam di reaktor [8]

Selain pengadukan, agar digestasi anaerobik berlangsung secara mendalam, nilai $\mathrm{pH}$ sangatlah penting. $\mathrm{pH}$ dampak langsung pada kemajuan pencernaan dan produk. $\mathrm{pH}$ efluen dari reaktor menunjukkan stabilitas sistem dan variasinya menunjukkan kurangnya kapasitas buffer sistem. Bakteri hidrolitik, asidogen, dan metanogen memiliki $\mathrm{pH}$ optimal sendiri untuk laju reaksi maksimum [9].

$\mathrm{pH}$ mempengaruhi kesetimbangan kimia $\mathrm{NH}_{3}$, $\mathrm{H}_{2} \mathrm{~S}$ dan Asam Lemak Volatil (VFA), yang dapat menghambat aktivitas mikroorganisme. Kisaran $\mathrm{pH}$ ideal untuk pencernaan anaerob ialah 6,8-7,4 [10]. Penambahan natrium hidroksida atau natrium bikarbonat dapat mengontrol penurunan nilai $\mathrm{pH}$ dan meningkatkan alkalinitas campuran. Alkalinitas adalah jumlah jumlah basa dalam reaktor untuk menetralisir kondisi asam dalam digester sehingga $\mathrm{pH}$ digester stabil. Adanya alkalinitas dalam suatu reaktor dengan konsentrasi tertentu dapat menjadi penyangga (buffer) untuk menjaga $\mathrm{pH}$ dalam kondisi netral pada saat terjadi penambahan asam, sehingga keseimbangan proses secara keseluruhan tetap dapat berjalan normal. Ketika $\mathrm{pH}$ dibiarkan jatuh, maka sistem akan berhenti karena bakteri pembentuk metana akan mati [11].

\section{Metodologi Penelitian}

Bahan baku berupa LCPKS diperoleh dari pabrik kelapa sawit (PKS) PTPN III Unit Kebun Rambutan, Tebing Tinggi, Provinsi Sumatera Utara dan starter dari Pilot Plant Pembangkit Listrik Tenaga Biogas, Pusdiklat LPPM USU, Medan. Starter dan LCPKS yang telah dikarakterisasi dimasukkan ke dalam fermentor dengan perbandingan $20 \%$ starter dan $80 \%$ LCPKS. Reaktor dioperasikan dengan variasi laju pengadukan $(\omega) 100 \mathrm{rpm}, 150 \mathrm{rpm}, 100 \mathrm{rpm}, 250 \mathrm{rpm}$, $300 \mathrm{rpm}$ pada suhu $55{ }^{\circ} \mathrm{C}$. Kondisi campuran diatur hingga campuran memiliki pH $7 \pm 0,2$, dan $M$ Alkalinity 2.500-5.000 mg/L. Pengontrolan $\mathrm{pH}$ dilakukan dengan menambahkan Natrium Bikarbonat $\left(\mathrm{NaHCO}_{3}\right)$ ke dalam campuran. Setelah $\mathrm{pH}$ dan $M$ Alkalinity yang diinginkan tercapai, campuran dikarakterisasi dan dianggap hasil karakterisasi tersebut sebagai data pada $\mathrm{t}=0$. Setelah suhu yang diinginkan tercapai dan dijaga stabil, dalam hal ini suhu termofilik $\left(55^{\circ} \mathrm{C}\right)$, proses mulai dijalankan. Bioreaktor beroperasi terus menerus sampai biogas tidak dihasilkan lagi. Data dikumpulkan berupa $\mathrm{pH}$, alkalinitas dan volume biogas. Data yang diperoleh ditabulasikan setiap hari. Rangkaian alat dapat dilihat pada gambar 1 .

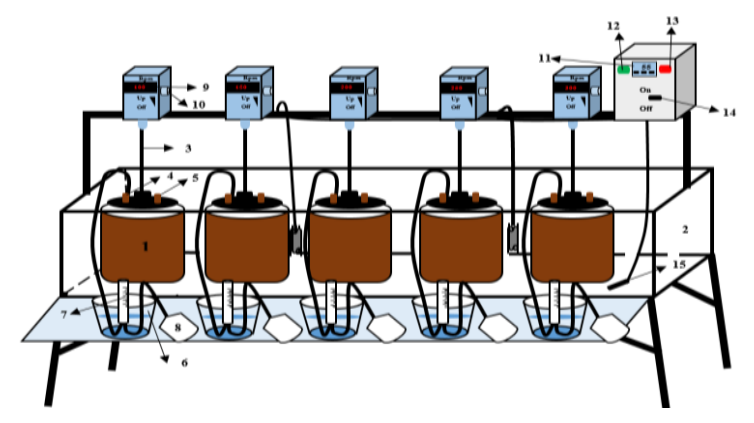

Gambar 1. Rangkaian Peralatan

Keterangan Gambar :
1. Jar fermentor
2. Water bath
9. Penampung gas
3. Stirrer
4. Sampling injector
5. Termometer
6. Water trap
7. Gelas Ukur
10. Kecepatan pengaduk
11. Controller
12. Temperature controller
13. Lampu indikator on
14. Lampu indikator off
15. On/off

8. Thermocouple

\section{Hasil}

\section{Karakterisasi Bahan Baku}

Penelitian ini menggunakan bahan baku berupa limbah cair pabrik kelapa sawit (LCPKS) dari Pabrik Kelapa Sawit (PKS) Rambutan, PT Perkebunan Nusantara III, Kabupaten Serdang Bedagai dan starter yang berasal dari digester anaerobik methanogenik 3000 L, biogas plant, USU. Karakteristik LCPKS dan starter yang digunakan pada penelitian ini disajikan pada Tabel 1 dan Tabel 2. 
Tabel 1. Karakteristik LCPKS Perkebunan Nusantara III, Pabrik Kelapa Sawit (PKS) Rambutan, Kabupaten Serdang Bedagai

\begin{tabular}{|l|l|r|c|}
\hline \multicolumn{1}{|c|}{ Parameter } & Satuan & \multicolumn{1}{c|}{ Hasil } & Metode \\
\hline $\mathrm{pH}$ & & 4,7 & $\mathrm{pH}$ Meter \\
\hline M-Alkalinitas & & 1400 & Titrasi \\
\hline COD & $(\mathrm{mg} / \mathrm{L})$ & 68131,87 & APHA 5220B \\
\hline VS & $(\mathrm{mg} / \mathrm{L})$ & 32000 & APHA 2540E \\
\hline VSS & $(\mathrm{mg} / \mathrm{L})$ & 11738 & APHA 2540E \\
\hline
\end{tabular}

Tabel 2. Karakteristik Starter, Biogas Plant, USU

\begin{tabular}{|l|c|r|c|}
\hline \multicolumn{1}{|c|}{ Parameter } & Satuan & Hasil & Metode \\
\hline $\mathrm{pH}$ & & 8,4 & $\mathrm{pH}$ Meter \\
\hline M-Alkalinitas & & 4100 & Titrasi \\
\hline $\mathrm{COD}$ & $(\mathrm{mg} / \mathrm{L})$ & 37500 & APHA 5220B \\
\hline VS & $(\mathrm{mg} / \mathrm{L})$ & 14000 & APHA 2540E \\
\hline VSS & $(\mathrm{mg} / \mathrm{L})$ & 16000 & APHA 2540E \\
\hline
\end{tabular}

Berdasarkan Tabel 1 dan Tabel 2 dapat dilihat bahwa LCPKS dan starter berpotensi untuk dijadikan sebagai bahan baku pembuatan biogas. LCPKS mengandung COD yang cukup untuk digunakan sebagai bahan baku yaitu diatas $350 \mathrm{mg} / \mathrm{L}$ (standar mutu limbah) [12] dan starter mengandung konsentrasi mikroorganisme tinggi yang ditandai dari nilai VSS yaitu $16000 \mathrm{mg} / \mathrm{L}$ yang berperan dalam digestasi anaerobik. Pencampuran kedua bahan diharapkan akan menyeimbangkan kebutuhan nutrisi sehingga mikroorganisme dapat tumbuh dan mendegradasi LCPKS menjadi biogas. Dilakukan pengontrolan $\mathrm{pH}$ dan alkalinitas campuran dengan menambahkan buffer yaitu $\mathrm{NaHCO}_{3}$ agar proses dapat berlangsung seragam dan maksimal. Karakteristik campuran LCPKS dan starter dapat dilihat pada tabel 3.

Tabel 3. Karakteristik Campuran LCPKS dan Starter

\begin{tabular}{|l|c|r|c|}
\hline \multicolumn{1}{|c|}{ Parameter } & Satuan & Nilai & Metode \\
\hline $\mathrm{pH}$ & & 7 & $\mathrm{pH}$ Meter \\
\hline M-Alkalinitas & & 3500 & Titrasi \\
\hline $\mathrm{COD}$ & $(\mathrm{mg} / \mathrm{L})$ & 55357 & APHA 5220B \\
\hline VS & $(\mathrm{mg} / \mathrm{L})$ & 44000 & APHA 2540E \\
\hline VSS & $(\mathrm{mg} / \mathrm{L})$ & 12000 & APHA 2540E \\
\hline
\end{tabular}

\section{Pengaruh Laju Pengadukan terhadap pH dan M- Alkalinity}

$\mathrm{pH}$ dan alkalinitas merupakan parameter yang dapat dijadikan sebagai acuan peninjauan stabilitas proses digestasi anaerobik di dalam digester. $\mathrm{pH}$ adalah parameter yang paling signifikan yang mempengaruhi kinerja dan stabilitas digester anaerob.
Hal ini dikarenakan pertumbuhan mikroorganisme sangat sensitif terhadap pH. Setiap kelompok bakteri membutuhkan kisaran $\mathrm{pH}$ yang berbeda selama pertumbuhan [13]. Profil $\mathrm{pH}$ dan alkalinitas dapat dilihat pada gambar 2 .

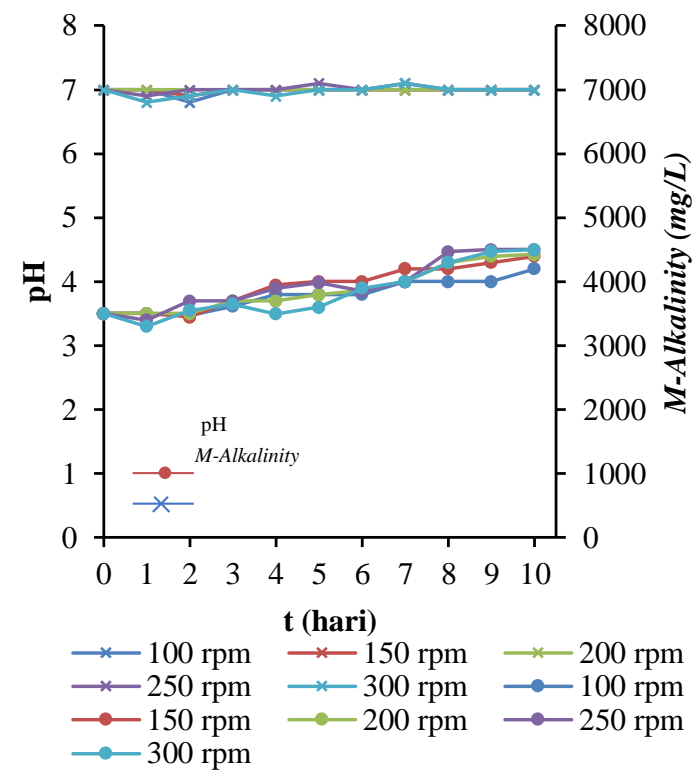

Gambar 2. Pengaruh Laju Pengadukan terhadap pH dan M-Alkalinity

Gambar 2. menunjukkan nilai pH dan alkalinitas awal dan akhir percobaan. Nilai $\mathrm{pH}$ berkisar antara 6,8 hingga 7,1 dan alkalinitas antara 3.500-4.500 mg/L sehingga menghasilkan lingkungan yang cocok untuk degradasi LCPKS. Pada tahap awal, pH mengalami penurunan untuk setiap laju pengadukan. Hal ini disebabkan dikarenakan terjadinya prevalensi VFA (volatiles fatty acid) [6]. Hal ini akan meningkatkan pertumbuhan bakteri asidogenik dikarenakan pertumbuhan ideal bakteri asidogenik berada pada rentang pH 5,5-6,5 [14]. Namun, Penurunan nilai pH akan merusak kondisi lingkungan hidup bakteri metanogenik di mana bakteri metanogenik dapat tumbuh pada rentang $\mathrm{pH}$ 6,5-8,2 [10], sehingga biogas yang dihasilkan tidak optimal diakibatkan bakteri aktif mengalami penurunan kinerja atau hilang. Jika nilai $\mathrm{pH}$ turun di bawah 6,5, maka produksi asam organik oleh bakteri hidrolitik dapat menyebabkan penurunan $\mathrm{pH}$ yang lebih drastis dan proses fermentasi akan berhenti. Maka penggunaan larutan buffer sangat dibutuhkan untuk meningkatkan alkalinitas campuran dengan meningkatkan nilai $\mathrm{pH}$ campuran.

Hasil alkalinitas yang ditampilkan pada gambar 2 menunjukkan pola yang mirip dengan $\mathrm{pH}$. Penurunan $\mathrm{pH}$ pada tahap awal dikontrol kembali oleh alkalinitas tinggi dari keberadaan natrium bikarbonat $\left(\mathrm{NaHCO}_{3}\right)$. Adanya pengadukan dapat meningkatkan dan mempercepat efisiensi kerja digester dalam menstabilkan kembali $\mathrm{pH}$ dan alkalinitas campuran. Pada gambar 2 dapat dilihat bahwa adanya 
peningkatan laju pengadukan $(\omega)$ seiring dengan peningkatan kestabilan nilai $\mathrm{pH}$ dan alkalinitas. Hasil kerja digester dapat dilihat juga pada akumulasi volume biogas yang dihasilkan. Akumulasi volume biogas pada tiap-tiap pengadukan disajikan pada gambar 3 .

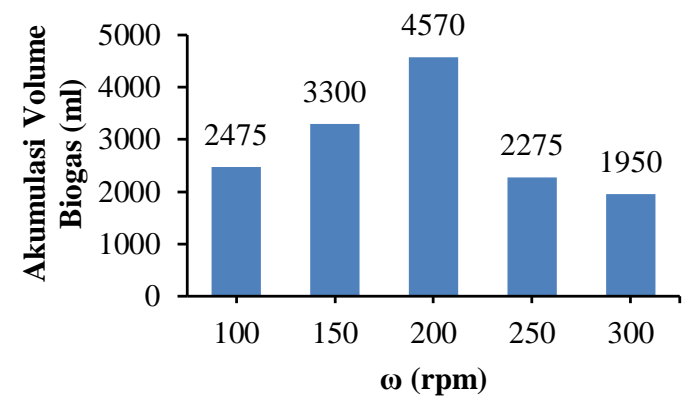

Gambar 3. Pengaruh Laju Pengadukan terhadap Akumulasi Volume Biogas

Gambar 3 menunjukkan profil produksi total biogas mengalami peningkatan seiiring meningkatnya laju pengadukan $(\omega)$ hingga pengadukan $200 \mathrm{rpm}$ dengan kenaikan sebesar 33,33\% dan $84,65 \%$ jika dibandingkan dengan volume biogas pada laju pengadukan $(\omega) 100 \mathrm{rpm}$. Hal ini sesuai dengan Demollari, 2017 di mana produksi biogas meningkat dengan meningkatkan kecepatan pengadukan. Akan tetapi, pada laju pengadukan ( $\omega) 250 \mathrm{rpm}$ dan $300 \mathrm{rpm}$ jumlah volume biogas mengalami penurunan masingmasing sebesar 50,22\% dan 57,33\% dibandingkan volume biogas pada laju pengadukan $(\omega) 200 \mathrm{rpm}$. Hal ini seiring dengan nilai $\mathrm{pH}$ dan $\mathrm{M}$-Alkalinity di mana adanya laju pengadukan terlalu tinggi mengakibatkan kestabilan $\mathrm{pH}$ terganggu.

Oleh karena itu, laju pengadukan terbaik diperoleh pada laju pengadukan $200 \mathrm{rpm}$ di mana akumulasi volume biogas mencapai $4570 \mathrm{ml} \mathrm{(457}$ $\mathrm{ml} /$ hari) dan $\mathrm{pH}$ campuran stabil yaitu 7 selama proses digestasi anaerobik berlangsung.

\section{Kesimpulan}

Nilai $\mathrm{pH}$ dan alkalinitas selama proses digestasi anaerobik berada pada rentang optimum yaitu masingmasing pada rentang 6,8-7,1 dan 3.500-4.500 mg/L. Stabilisasi digester terbaik diperoleh pada laju pengadukan $200 \mathrm{rpm}$ dan mencapai akumulasi volume biogas tertinggi yaitu sebesar $457 \mathrm{ml} /$ hari.

\section{Ucapan Terima Kasih}

Penulis menyatakan terimakasih atas kontribusi staf Laboratorium Ekologi, Universitas Sumatera Utara dalam melakukan aspek-aspek eksperimental dari penelitian ini.

\section{Daftar Pustaka}

[1] A. Rajani, Kusnadi, A. Santosa, A. Saepudin, S. Gobikrishnan, and D. Andriani, "Review on Biogas from Palm Oil Mill Effluent (POME): Challenges and Opportunities in Indonesia," IOP Conf. Ser. Earth Environ. Sci., vol. 293, no. 1, 2019.

[2] M. Rashid, N. Shakib, and T. Rahman, "Biogas Production from POME by Optimum Level of Inputs," Smart Grid Renew. Energy, vol. 10, no. 08, pp. 203-212, 2019.

A. Das and C. Mondal, "Comparative Kinetic Study of Anaeriobic Treatment of Thermally Pretreated Source-Sorted Organic Market Refuse," J. Eng. (United States), vol. 2015, no. December, 2015.

[4] J. Kainthola, A. S. Kalamdhad, and V. V. Goud, "A Review on Enhanced Biogas Production from Anaerobic Digestion of Lignocellulosic Biomass by Different Enhancement Techniques," Process Biochem., vol. 84, no. May, pp. 81-90, 2019.

[5] N. Shakib and M. Rashid, "Biogas Production Optimization from POME by Using Anaerobic Digestion Process," J. Appl. Sci. Process Eng., vol. 6, no. 2, pp. 369-377, 2019.

[6] M. A. F. Hamzah, J. M. Jahim, P. M. Abdul, and A. J. Asis, "Investigation of Temperature Effect on Start-Up Operation from Anaerobic Digestion of Acidified Palm Oil Mill Effluent," Energies, vol. 12, no. 13, 2019.

[7] L. Gyenge, S. Crognale, S. Lányi, B. Ábrahám, and B. Ráduly, "Anaerobic digestion of corn-DDGS: Effect of $\mathrm{pH}$ control, Agitation and batch Repetition," UPB Sci. Bull. Ser. B Chem. Mater. Sci., vol. 76, no. 4, pp. 163-172, 2014.

[8] M. Aznury, Jaksen, A. Hasan, and R. Artindah, "The Production of Biogas from Palm Oil Mill Effluent as Substrate with Variation of Agitation Speed with Fed-batch System," MATEC Web Conf., vol. 268, 2019.

[9] S. Panigrahi and B. K. Dubey, "A critical review on operating parameters and strategies to improve the biogas yield from anaerobic digestion of organic fraction of municipal solid waste," Renew. Energy, vol. 143, pp. 779-797, 2019.

[10] A. Ceron-Vivas, K. T. Cáceres-Cáceres, A. Rincón-Pérez, and A. A. Cajigas, "Influence of $\mathrm{pH}$ and the $\mathrm{C} / \mathrm{N}$ ratio on the biogas production of wastewater," Rev. Fac. Ing. Univ. Antioquia, no. 92, pp. 70-79, 2019.

[11] H. H. A. Matin and Hadiyanto, "Biogas Production from Rice Husk Waste by using Solid State Anaerobic Digestion (SSAD) Method," E3S Web Conf., vol. 31, 2018.

[12] Anonim, KepMen LH nomor 5/ 2014, Peraturan Menteri, Indonesia, 2014, p.1-10. 
[13] S. K. Pramanik, F. B. Suja, S. M. Zain, and B. K. Pramanik, "The anaerobic digestion process of biogas production from food waste: Prospects and constraints," Bioresour. Technol. Reports, vol. 8, no. July, p. 100310, 2019.

[14] Y. C. Chou and J. J. Su, "Biogas production by anaerobic co-digestion of dairy wastewater with the crude glycerol from slaughterhouse sludge cake transesterification," Animals, vol. 9, no. 9, 2019.

[15] E. Demollari, "Temperature and Stirring Effect of Biogas Production from Two Different Systems," Am. J. Energy Eng., vol. 5, no. 2, p. 6, 2017. 